\title{
Construction and Reconstruction of Ethnicity in Retail Landscapes: Case Studies in the Toronto Area
}

\section{Zhixi Cecilia Zhuang}

To cite this article: Zhixi Cecilia Zhuang (2015) Construction and reconstruction of ethnicity in retail landscapes: case studies in the Toronto area, Journal of Urban Design, 20:5, 677-697, DOI: 10.1080/13574809.2015.1071652

To link to this article: http://dx.doi.org/10.1080/13574809.2015.1071652

\begin{abstract}
:
The ethnic retail phenomenon is a highly recognizable symbol of Canada's multiculturalism. However, very little research has examined how 'ethnicity' is reflected through physical retail spaces or how a neighbourhood's ethnic identity is constructed and reconstructed through ethnic retail spaces. Interviews and surveys with key informants in four ethnic retail neighbourhoods in Toronto, Canada revealed the dynamics of changing ethnic retail landscapes, how ethnicity may be physically manifested, and the complex meanings behind architectural or structural changes. The results can inform municipalities about the importance of appropriate public policies in the areas of urban design, neighbourhood identity, and economic development to help enhance the flourishing ethnic landscapes.
\end{abstract}

\section{Keywords:}

Ethnic Expression, Ethnic Retail Landscape, Ethnicity, Toronto

\section{Introduction}

Patterns of immigration to Canada have changed significantly over the past decades as policy amendments have provided opportunities for immigration from 'non-traditional' (e.g., nonEuropean) source countries. ${ }^{1}$ These new waves of immigrants have significantly transformed the urban and suburban landscapes of Canadian metropolitan regions. Manifestations of ethnocultural diversity are readily apparent in ethnic retail strips and centres: these diverse representations of various ethnic groups physically differentiate them from their 'mainstream' (e.g., not ethno-specific) counterparts. These retail areas are easily identified through store signs, store merchandise, exterior and interior decoration, and street furniture. These areas are also in flux; different waves of immigrants shape ethnic retail spaces as they settle and subsequently disperse. Despite the ethnic retail phenomenon being a highly recognizable symbol of Canada's multiculturalism, very little research has examined commercial ethnic landscapes, specifically how 'ethnicity' is reflected through these physical spaces and how the ethnic identity of a neighbourhood may be constructed and reconstructed through ethnic retail spaces (Buzzelli, 2001; Groth, 1997; Lara, 2012; Noble, 1992; Upton, 1986). 
Here, the term 'landscape' refers to more than scenery: it refers to the interactions between people and place (Groth, 1997, p. 1). In the context of ethnic retailing, interactions between ethnic entrepreneurs (the primary focus of this paper) and place can strongly affect urban spaces through the diverse business practices that occur in them every day. The construction and reconstruction of retail landscapes reflects the needs, values, cultural identities, social norms, and interactions of ethnic entrepreneurs with the business environment. Tracing the changing ethnic retail landscape can help reveal how and why ethnic identity is expressed, and how it transforms and redefines the retail landscape. For municipalities with large numbers of immigrants, it is especially important to clarify the nature and meaning of multicultural communities and their ethnic expressions in retail spaces to ensure public policies facilitate and enhance flourishing ethnic landscapes.

This study examined the changing ethnic retail landscapes in Toronto, Canada. Many inner-city neighbourhoods feature strips of concentrated ethnic businesses, with well-recognized names such as Chinatown, India Bazaar, Little Italy, Greektown, Little Portugal, Korea Town, and Little Poland. Suburban ethnic businesses tend to manifest in the form of ethnic centres or shopping malls: Wang and Zhong (2013) reported that 57 of the 66 Chinese shopping centres (86\%) developed in the Toronto Census Metropolitan Area (TCMA) over the past two decades were located in the 'ethnoburbs.' Emerging ethnic retail activities inevitably affect store facades, window displays, signage, architectural and/or decoration treatments, as well as the cultural meanings they convey and the atmosphere of the neighbourhood.

This study explored the manifestations of ethnicity in urban and suburban retail spaces to help clarify the meanings underlying visual changes, investigating questions like: How does ethnicity physically manifest in the changing retail landscape? What meanings do the changing landscapes convey? What are the implications for municipalities? It focused on four ethnic commercial areas in Toronto: East Chinatown, Gerrard India Bazaar, and Corso Italia in Toronto's inner city, and the Pacific Mall in the City of Markham, a suburban municipality adjacent to the City of Toronto and part of the TCMA (Figure 1). ${ }^{2}$ These areas were selected because they represent Toronto's multicultural mosaic and diverse immigration histories. They also enable comparisons among groups and between inner-city retail strips and a suburban mall. A total of 74 key informant interviews and 40 shopper intercept surveys were conducted, along with extensive field observations and photographic documentation. The results reveal the dynamics of the changing ethnic retail landscapes, various ways and degrees in which ethnicity may be manifested, and the complex meanings behind architectural or structural changes. The findings contribute valuable empirical data and can inform municipalities with major immigrant settlements about the ethnic retail phenomenon, its physical imprints on urban landscapes, and issues related to public policy-making in urban design, neighbourhood identity, and economic development. 


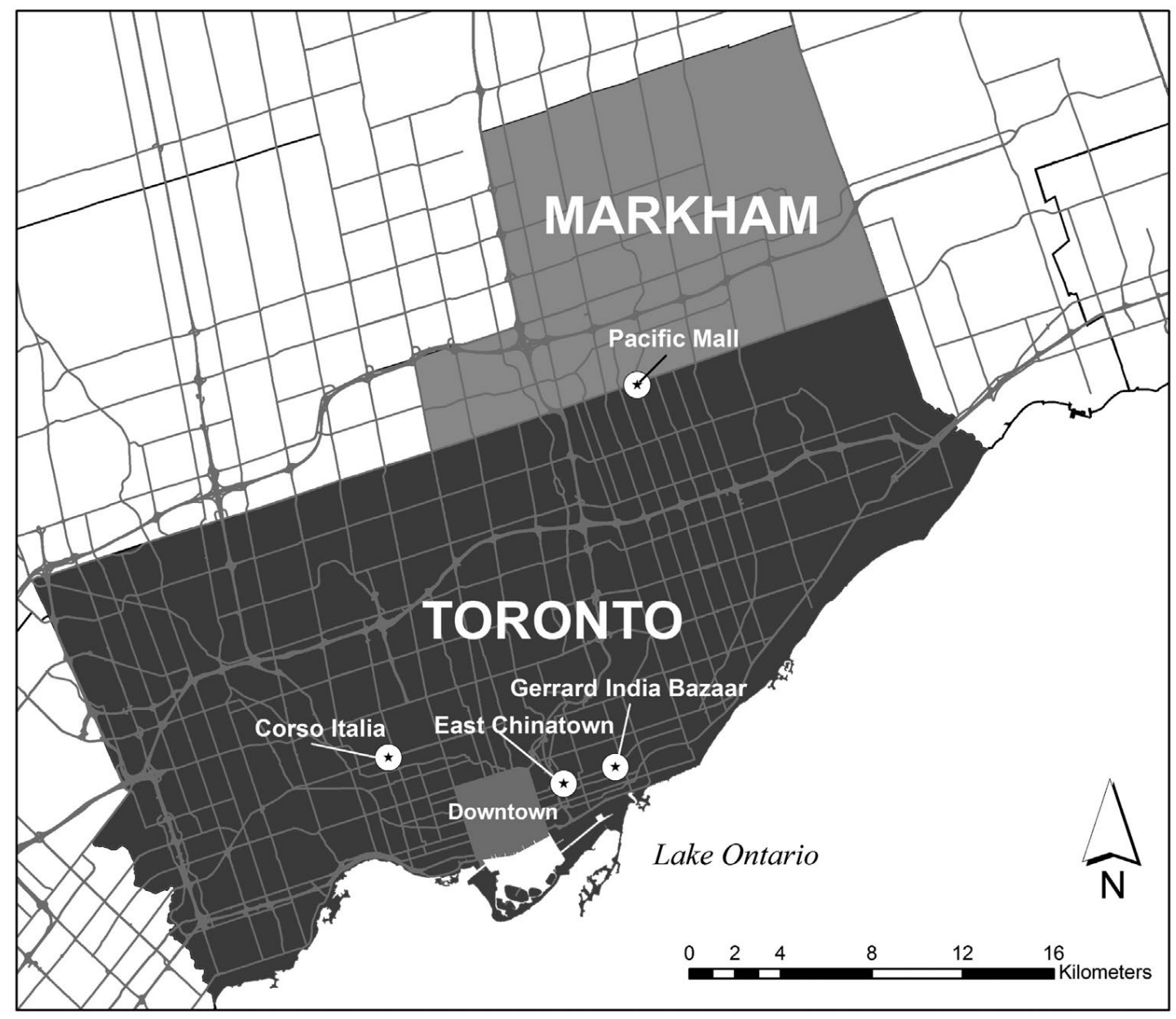

Figure 1. Map of the four case studies. Map produced by Cornel Campbell.

\section{Study of Ethnic Landscapes}

Considerable attention has been paid to pre-WWII ethnic communities and residential settlements, as well as vernacular architecture in semirural settings (Groth, 1997; Noble, 1992; Upton, 1986). However, successive waves of immigrants have also had effects on urban landscapes, which have yet to be explored extensively. One major reason for this research gap is the dominant assimilationist assumption that immigrants adopt the norms and practices of the dominant group soon after their settlement, while their ethnic distinctiveness is minimized through the assimilation process (Buzzelli, 2001; Li, 2009). Gans coined the term 'symbolic ethnicity,' arguing that 'there has been no [ethnic] revival, and that acculturation and assimilation continue to take place" (1979, p. 1). Using later generations of Catholic and Jewish Americans as an example, he defined 'symbolic ethnicity' as "a nostalgic allegiance to the culture of the immigrant generation, or that of the old country; a love for and a pride in a tradition that can be felt without having to be incorporated in everyday behavior" (ibid., 9). From this perspective, ethnicity is mainly associated with personal perspectives as opposed to a group identity and is marked by superficial symbols and icons of the culture. Zelinsky (1991), who at first insisted on a uniform, 'assimilated' version of symbolic ethnicity and questioned the authenticity of ethnic 
landscapes, describing them as 'exotic tidbits' and 'visual fakery' (pp.34-35), later coined the term 'heterolocalism' to better describe the socio-spatial behaviour of immigrant ethnic communities (2001). Based on his observations of non-Caucasian immigrants and people of colour in the US, this term refers to how immigrant communities are not only located in a dispersed manner on a metropolitan, regional, national, or even transnational scale, they also tend to maintain strong ethnic community ties that help define and express their ethnic identity.

Among the few scholars who have explored the diversity of ethnic landscapes, Hayden $(1995,1997)$ defined four elements of ethnic urban landscapes based on her research in Los Angeles - vernacular buildings, ethnic spatial patterns, ethnic vernacular arts traditions, and territorial histories - and encouraged using urban public history (the social history of public space), to gain a better understanding of minorities' social lives and their imprints on urban landscapes. Kaplan and Li (2006) emphasized the impact of ethnic commercial activity on the development of ethnic landscapes as "ethnic businesses make and mark ethnic places" (p. 10). Olson and Kobayashi (1993) focused on Montreal streets, exploring how people from different cultures have "modified Canadian urban landscapes to express their identities" (p. 147) via architecture features, people's encounters in public space, the adaptation of places of worship, small ethnic businesses, and festivals, and especially the appropriation of landscape by small ethnic businesses to create a sense of identity. These findings provide a useful framework to understand the changing nature of ethnicity in urban form, especially in the Canadian context where ethnic succession is a key process affecting ethnic landscapes.

Early immigrant groups from the British Isles and France (Canada's 'founding nations') created dominant forms and building structures long before the 'new' immigrants arrived. Later, when newcomers inherited the existing neighbourhoods, hybrid forms emerged, incorporating their ethnic distinctiveness into existing landscapes and creating new ones - such as the transformation of Little Britain into Little Italy in Toronto (Buzzelli, 2001) and the East-meetsWest style of Chinatowns across the country (Lai, 1988). Even with no changes to the structures, forms, and materials of buildings in an area, rich ethnic identity can transform and be expressed through occupancy, spatial use patterns, aesthetics, decorations, and the meaning attached to even minor changes (Conzen, 2010).

Ethnic successions and changes in ethnic landscapes can contribute to the revitalization of urban areas. The Italian, Portuguese, and Sino-Vietnamese community experiences in Toronto reveal that although some former residents consider these groups of people to have 'invaded' their neighbourhood, new ethnic businesses and communities have sustained the economic vitality of these areas and redefined the neighbourhood characteristics (Buzzelli, 2001; Teixeira, 2006; Phan and Luk, 2008). This has also been the case in other countries: Mexicantown in Detroit, Little Turkey in Sydney, and Vietnamese commercial nodes in Northern Virginia all exemplify how ethnic businesses can help revitalize derelict urban areas (Collins \& Kunz, 2009; Lara, 2012; Wood, 1997), while at the same time constructing and reconstructing the ethnic identity of the neighbourhoods. 


\section{Construction and Expression of Ethnicity in Retail Landscapes}

Jenkins defined 'ethnicity' as a social identity of cultural differentiation constructed in social interaction; it is "collective and individual, externalized in social interaction and the categorization of others, and internalized in personal self-identification" (2008, pp. 14). In other words, ethnicity is neither fixed nor unchanging: it can be perceived by self and/or others as sharing "a unique set of cultural and historical commonalities" (Zelinsky, 2001, p. 43). Drawing on this definition, some contemporary scholars have examined how ethnicity shapes and is shaped by city culture, the local economy, and globalization. Specific research topics have included cuisine, fashion, consumption behaviours and marketing strategies, 'Disneyfication' and symbolism, city culture and commercialized expression, and tourism and the global economy (Abizadeh \& Ghalam, 1994; Conzen, 2010; Cook, Crang \& Thorpe, 1999; Dwyer \& Crang, 2002; Halter, 2000; Jackson, 2002; Kaltmeier, 2011; Koc \& Welsh, 2002; Zukin 1995). Some of the terms used in these studies, e.g., 'fashioning ethnicities,' 'shopping for identity: the marketing of ethnicity,' 'selling ethnicity,' and 'practising identities,' illustrate how ethnicity has become fashionable - 'ethnic chic' (Jackson, 2002) - and marketable because diversity 'sells' (Dwyer \& Crang, 2002).

The current fashionable and marketable nature of ethnicity can be attributed to two primary factors. First, dramatic social changes during the latter half of the previous century (e.g., the civil rights movement, human rights legislation, and increased international travel and consumption) have decreased racial discrimination: ethnic goods have now "become a part of daily fare for the mainstream public" (Qadeer, 1999, p. 4). The international cultural goods giant Hallmark has promoted and labeled this era as the "Age of Multiculturalism" (Halter, 2000, p. $65)$. Second, with this awareness and sensitivity to multiculturalism, ethnicity has become associated with commodity and economy. Culture and commerce are no longer seen as separate entities, but as an encompassing 'commercial culture' that commodifies difference (Jackson, 2002). Cultural production remains the 'symbolic economy' of the city (Zukin, 1995).

Before research about ethnicity was common, discussions of ethnic landscapes mainly focused on how ethnic neighbourhoods were racially stereotyped, oppressed, or made the target of so-called urban renewal and thus demolished (Anderson, 1988, 1991; Hayden, 1997; Olson \& Kobayashi, 1993; Thompson, 1989). However, the new cultural pluralism has resulted in a revival of ethnic expression by ethnic entrepreneurs, developers, and local regulatory authorities. Because ethnicity can be commodified as part of the 'ethnic chic' trend among the mainstream public, culture and economics are intertwined in the process of ethnic gentrification (Hackworth \& Rekers, 2005; Loukaitou-Sideris, 2002). This commodification also boosts tourism development and transforms ethnic neighbourhoods into places of leisure and consumption (Rath, 2007). Ethnic festivals are a popular way to attract "masses of people, including people in the mainstream" (ibid.,10), even if they were "established with the intention of catering to the (material or emotional) needs of the in-group only" (ibid., 12). Many cities have used ethnic themes to promote development of ethnic neighbourhoods, e.g., the Chinese Quarter in Birmingham (Chan, 2007); Little Italy in Manchester (Taylor, 2000); Chinatowns in Antwerp and 
Brussels (Pang, 2012), Vancouver (Anderson, 1991), and Melbourne (Anderson, 1990); Banglatown in London (Shaw, 2010); Chinatown, Little Italy, Vietnamatta, and Little Turkey in Sydney (Collins \& Kunz, 2009); Little Sweden in Kansas (Schnell, 2003); and Plaza Mexico in Los Angeles (Irazabal \& Gomez-Barris, 2007). In most cases, local regulatory authorities and community organizations serving as the 'critical infrastructure' of the symbolic economy (Zukin, 1995), together with developers, are the major actors in promoting the production and consumption of ethnic spaces and (re)shaping urban ethnic landscapes.

Some scholars have explored authenticity within these landscapes. Collins and Kunz studied four ethnic precincts in Sydney, questioning "the problem of the credibility and authenticity," specifically "who is 'authorized' to claim authenticity, how that authenticity is symbolized and what employees and employers in ethnic enterprises have to do to generate that authenticity" (2009, pp. 42-43). After interviewing merchants and surveying co-ethnic, cocultural, and other customers, they concluded, "What constitutes an 'authentic' ethnic or cultural eating or tourist experience could vary according to the different standpoints of those who participate in the daily life of the ethnic precinct" (ibid., 44). Therefore, the perceptions of authenticity could be "subjective, multivocal and sometimes contradictory" (ibid., 61). Similarly, $\mathrm{Li}$ argued that it can be difficult to determine which kinds of physical expression of ethnic identity are 'authentic' (2009). Schnell explored authenticity in the interactions between tourism, culture, and ethnicity in Little Sweden in Lindsborg, Kansas, commenting, "it is also quite possible to market one's heritage to outsiders and still maintain a deep, personal, emotional attachment to one's identity; it is possible to sell something you believe in" (2003, p. 65). In other words, commercialization does not always equal "cultural corruption” (ibid., p. 66).

Ethnicities manifested in urban landscapes are thus multiple and fluid, constructed internally by the ethnic community and externally by outsiders who have interests in ethnic spaces. The ethnicity expressed in retail landscapes conveys multi-layered meanings that reflect both ethnic pride and commercial lure, which points to the need to study how ethnicity is constructed and reconstructed along with day-to-day retail activities, the relationship between culture and commerce, and the major players (e.g., ethnic entrepreneurs, developers, and city officials) who contribute to the making of ethnic retail landscapes. The results can help inform municipalities about the dynamics and complexity of ethnic urban landscapes, and help them address issues related to design guidelines, neighbourhood identity, and economic development.

\section{Methodology}

Few studies have focused on ethnic retail landscapes, so there is a need for more exploratory empirical studies on this topic. Case study methods are often recommended for exploratory research, and multiple case studies are more appropriate when many actors are involved and the subject matter is complex - using more than one case also increases the generalizability of the results (Yin, 2009). Triangulation of data collection modes and data sources is also important to ensure quality control (Robson \& Neuman, 2012). This study examined four case studies and used multiple methods of data collection to capture the dynamics of the changing ethnic retail 
landscapes: local historic records for each area; neighbourhood demographic profiles based on the 2006 Census; annual business survey data (2000-2009) retrieved from the Centre for the Study of Commercial Activity (CSCA) at Ryerson University; field observations of business operations and interactions between people, businesses, and public spaces; photographic documentation of physical features of the business environment; qualitative interviews with key informants; and intercept surveys with shoppers.

As the literature suggests, perceptions or meanings of an 'ethnic landscape' may vary between the producers of the landscape and its consumers, between community members and outsiders, and between various stakeholders. To obtain a wide spectrum of perspectives on the construction and reconstruction of ethnicity, the author conducted 74 in-person interviews and 40 shopper intercept surveys with the 'producers' (e.g., ethnic entrepreneurs) and 'consumers' (e.g., shoppers) of the retail landscapes, as well as members of the 'critical infrastructure' (e.g., city councillors, city planners, economic development officers, community leaders) (Table 1). First, 19 in-person information interviews were conducted with individuals who are knowledgeable about the study areas (e.g., business leaders, local librarians, community leaders, planners, academics). These open-ended interviews provided information about the areas and helped identify key issues and informants. Later, 55 semi-structured interviews and 40 intercept surveys with shoppers were conducted.

Table 1: Summary of Research Participants

$\mathrm{EC}=$ East Chinatown $; \mathrm{GIB}=$ Gerrard India Bazaar; $\mathrm{CI}=$ Corso Italia

* EC and GIB are in the same city ward, so city councillors, planners, and community leaders represented both areas.

\begin{tabular}{|c|c|c|c|c|c|c|}
\hline & & EC & GIB & CI & $\mathbf{P M}$ & Total \\
\hline \multirow{5}{*}{$\begin{array}{l}\text { Semi-structured } \\
\text { Interviews }\end{array}$} & Merchants & 7 & 7 & 8 & 12 & \multirow[t]{5}{*}{55} \\
\hline & $\begin{array}{l}\text { City Councillors and } \\
\text { Assistants }\end{array}$ & \multicolumn{2}{|c|}{$3 *$} & 3 & 1 & \\
\hline & Planners & \multicolumn{2}{|c|}{$1 *$} & 3 & 2 & \\
\hline & $\begin{array}{l}\text { Economic } \\
\text { Development } \\
\text { Officers }\end{array}$ & 1 & 1 & 1 & 1 & \\
\hline & Community Leaders & \multicolumn{2}{|c|}{$3 *$} & 1 & N/A & \\
\hline \multirow[t]{3}{*}{$\begin{array}{l}\text { Information } \\
\text { Interviews }\end{array}$} & $\begin{array}{l}\text { Business } \\
\text { Community }\end{array}$ & 2 & 1 & 1 & $\begin{array}{l}2 \text { property } \\
\text { managers }\end{array}$ & 19 \\
\hline & Local Librarians & 1 & 1 & 1 & 1 & \\
\hline & Community Leaders & \multicolumn{2}{|c|}{$1 *$} & N/A & N/A & \\
\hline
\end{tabular}




\begin{tabular}{|c|c|c|c|c|c|c|}
\hline & Academics & N/A & 1 & 1 & 2 & \\
\hline & & \multicolumn{4}{|c|}{2 specializing in general urban retail } & \\
\hline & Planners & \multicolumn{4}{|c|}{2} & \\
\hline Intercept Survey & Consumers & 8 & 10 & 10 & 12 & 40 \\
\hline \multicolumn{6}{|c|}{ Total } & 114 \\
\hline
\end{tabular}

Business participants (ethnic business owners/operators) were recruited through door-todoor visits or referrals from previous information interviews. In-person interviews were conducted in participants' stores or a nearby coffee shop/eatery, depending on interviewee preference. Merchants were asked about ethnic expression and its meanings in individual businesses (e.g., building facades, window displays, signage, architectural and/or decoration treatments) and in the overall shopping environment (e.g., streetscapes, sidewalk space, advertising and promotion of the area), using questions such as "do you like the ethnic theme expressed in your business area and why," "is it a major attraction to your customers," "is the ethnic theme beneficial to your own businesses," "would you be happy to add more cultural expressions to your storefront and why," "what would be the ideal image to represent the area and what are the possible ways to achieve that." To clarify how consumers interpret ethnic expression, every third shopper passing by on the street or in the mall was asked about the purpose of their shopping trip, what the place meant to them and why, and what they liked most about that particular retail area compared with others. Other stakeholders, such as city officials and community leaders, were recruited via telephone or email. For each study area, the author targeted the local city councillor or the councillor's assistant, the area or community planner, the transportation planner for specific projects, the designated commercial area advisor or economic development officer, and the local community agency that built partnership with the city and the businesses. In-person interviews were conducted in their offices or elsewhere, except for one interview conducted by telephone. These interviewees were asked their professional opinion about the physical expression of ethnicity in the retail areas and how their organizations could facilitate or hinder the ethnic expression that directly affects neighbourhood identity.

\section{Ethnic Succession: A Brief History of the Four Neighbourhoods}

The four neighbourhoods used as case studies developed in different ways, exemplifying various forms of ethnic succession. The Pacific Mall is the only planned ethnic shopping centre included in this study; the other three shopping strips in the inner city have evolved over time in an organic way. Each study area has a unique business profile, because each ethnic group has distinct cultural preferences and immigration histories. Ethnic and class resources have led to the development of different business niches, performances, and market sizes.

East Chinatown is located in the South Riverdale neighbourhood, which originated as an industrial, blue-collar neighbourhood. In the 1960s, a number of Chinese business owners chose to set up in the eastern part of the inner city because of its lower real estate and rental prices, 
proximity to a large public park, local public library, and convenient public transit connections to downtown (Lai, 1988; Wang, 1996). Due to an influx of Chinese immigrants and businesses, Chinese is the largest ethnic group in the neighbourhood and the commercial building stock has been adapted to the uses of Chinese businesses (Table 2). However, East Chinatown has been facing business decline since the 1990s and addressing this decline has been a key priority for local entrepreneurs. Businesses in East Chinatown mainly serve local Chinese residents by providing food stores and restaurants (40\%), and personal services (37\%).

Table 2: Ethnic Profiles of the Four Neighbourhoods

Source: City of Toronto 2008a, 2008b, 2008c, Statistics Canada 2006

\begin{tabular}{|c|c|c|c|}
\hline & Home Language & Ethnic Origin & Visible Minority Pop. \\
\hline East Chinatown & Chinese $23.1 \%$ & Chinese $33.1 \%$ & Chinese $31.6 \%$ \\
\hline India Bazaar & $\begin{array}{l}\text { Chinese } 13.6 \% \\
\text { Urdu } 2.6 \% \\
\text { Punjabi } 1.9 \%\end{array}$ & $\begin{array}{l}\text { Chinese } 22.1 \% \\
\text { Pakistani } 4.9 \% \\
\text { East Indian } 4.4 \%\end{array}$ & $\begin{array}{l}\text { Chinese } 20.3 \% \\
\text { South Asian 9.8\% }\end{array}$ \\
\hline Corso Italia & $\begin{array}{l}\text { Portuguese } 16.7 \% \\
\text { Italian } 10.9 \% \\
\text { Spanish } 6.5 \%\end{array}$ & $\begin{array}{l}\text { Portuguese } 30.7 \% \\
\text { Italian } 27.6 \% \\
\text { Spanish } 5.0 \%\end{array}$ & $\begin{array}{l}\text { Latin American 8.8\% } \\
\text { Black } 4.8 \%\end{array}$ \\
\hline Pacific Mall & Chinese $54.5 \%$ & Chinese $72.3 \%$ & Chinese $69.8 \%$ \\
\hline
\end{tabular}

The Gerrard India Bazaar is also located in the South Riverdale neighbourhood, about 1.5 kilometres east of East Chinatown. The area was initially settled by Europeans (Bauder \& Suorineni, 2010), but since the 1970s the commercial strip (once dominated by Anglo-Saxon and Greek stores) has been replaced by South Asian businesses catering to a once-booming regional ethnic market. It began accidentally when an immigrant from India purchased the Eastwood Theatre to show Bollywood films (Bauder \& Suorineni, 2010; Hackworth \& Rekers, 2005). Moviegoers flocked to the area, followed by other South Asian business owners. Since then, the India Bazaar has served as a business incubator, attracting South Asian entrepreneurs and an ethnically and geographically diverse clientele. Interestingly, the area has never had a significant local South Asian residential population to support the businesses in the Bazaar, reflecting a different development pattern from most traditional ethnic commercial neighbourhoods (Bauder \& Suorineni, 2010). As shown in Table 2, the area has a large proportion of Chinese residents. Additionally, residential gentrification has encroached into the area, deepening the "dissonance between commercial and residential identity" (Hackworth \& Rekers, 2005, p. 229). The predominance of retail (42\%) and food businesses (37\%) in the India Bazaar appeals to a larger community, especially regional South Asian and mainstream customers and tourists. 
The ethnic transformation in Corso Italia is remarkable, reflecting successions from British, Jews, Italians, and Portuguese to Latin Americans. The area was known as 'Little Britain' before the Second World War; with the influx of Italian immigrants to the area after the war, 'Little Britain' gradually became 'Little Italy' (Buzzelli, 2001). In 1984, the city even changed one of the street names from 'Elmwood Avenue' to 'Via Italia' (Byers \& Myrvold, 1999). In the late 1980s, the Italian community began to move to the outer suburbs, and the area became a destination for Portuguese immigrants and later Latin Americans (Table 2). Today, although the area is still referred to officially as 'Corso Italia,' the neighbourhood is ethnically diverse, featuring businesses owned by Italian, Portuguese, Asian, and Latino entrepreneurs and showcasing a large variety of cultural goods and foods. Its diversity is reflected in its residential population and commercial identity. Corso Italia specializes in the retail sector $(46 \%)$, especially high-end fashion stores that draw customers from all over the city, but its food-related businesses $(27 \%)$ and services $(27 \%)$ are more locally oriented.

The City of Markham, where the Pacific Mall is located, was once a bedroom community for Toronto, but during the last two decades has transformed into a fast-growing Chinese 'ethnoburb' (Wang \& Zhong, 2013): in 2006, visible minorities accounted for $65.4 \%$ of its population (Statistics Canada, 2010). In the 1990s, the Pacific Mall was developed in response to the increasing Chinese population and the booming Asian-oriented businesses, replacing an earlier retail complex on the site (Cullen Country Barns). The immediate neighbourhood has since become a major Chinese settlement area (Table 2). The Mall was officially designated as a tourist area by York Region, the regional government of Markham, enabling it to remain open even on statutory holidays. As a regional shopping centre and official tourist destination, the Mall targets a regional market with a prominent retail component (66\%), attracting Chinese and non-Chinese customers and tourists.

\section{Manifestations of Ethnicity: Ethnic Revival or Assimilation?}

Field observations and interviews in the four study areas revealed that ethnicity is manifested through architectural features, public space, public life, commercial activities, and ethnic festivals and branding; these findings are similar to previous reports (Dieterlen, 2014; Hayden, 1995; Lara, 2012; Olson \& Kobayashi, 1993; Rath, 2007). However, the four neighbourhoods differ from each other in that they have revived a strong ethnic expression, or have undergone assimilation with the goal of targeting wider audiences.

Ethnic entrepreneurs in East Chinatown and India Bazaar, and developers in Pacific Mall, are intensifying ethnic expression through physical structures. In East Chinatown, area merchants initiated the Chinese Archway, which was built in 2009 and features a traditional design, with three arches covered by a green ceramic tile roof (Figure 2). Instead of traditional Chinese motifs, the granite wall above the archway incorporates images of Chinese railway workers, as a tribute to the Chinese pioneers who contributed to Canada's history. Chinese archways are traditionally used to glorify or commemorate famous figures or events, and are 
treated as imposing monuments that preserve the essence of a family or a clan. Outside China, they may serve more as a popular, or even stereotypical, symbol translating Chinese culture into Western society. Chen described archways as "a well-recognized aesthetic, used in many places to indicate a tourist-friendly Chinese ethnicity" (2005, p. 93). Interviews revealed that merchants believed the archway would revitalize the declining business enclave, redefine the cultural image of the area, and attract more visitors: "the more cultural expression, the better."

Merchants in the India Bazaar also expressed interest in adopting a similar architectural approach, by turning the original Hindi movie theatre (then a rundown commercial and office complex) into a South Asian cultural centre (Figure 3). After discussing what a cultural centre should be, they decided that "the physical expression of our culture and identity should be something common for all South Asians," and should "help create harmony within the South Asian community and with the mainstream."

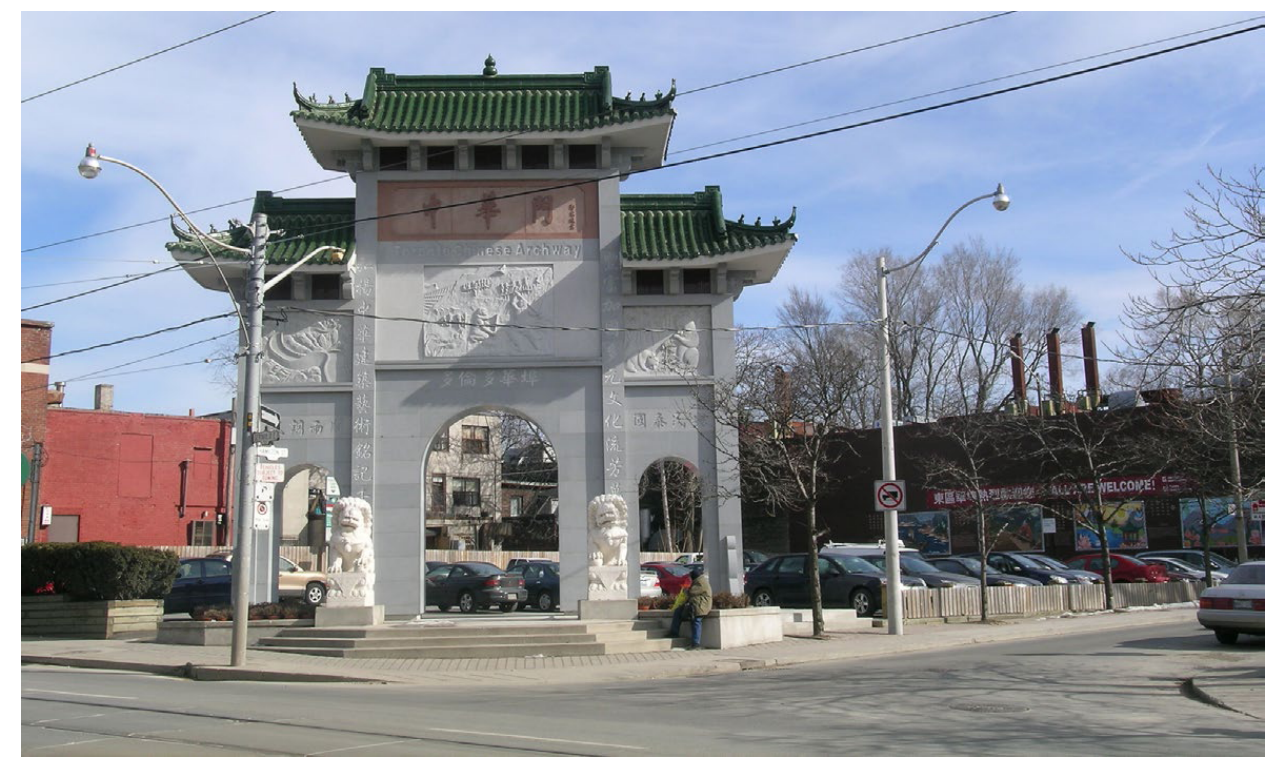

Figure 2. Local merchants consider the Chinese Archway in East Chinatown to be a symbol of the Chinese community.

The developers of Pacific Mall (originally from Israel) intended to recreate a Hong Kong market atmosphere inside the mall. They constructed a Chinese-themed 'Heritage Town' to attract customers, with Chinese artifacts and various decorations (Figure 4). Interviews with nonChinese customers revealed that most liked the cultural identity expressed in these design features because the Chinese shopping atmosphere differentiated it from mainstream malls, and also promoted understanding of different cultures. 


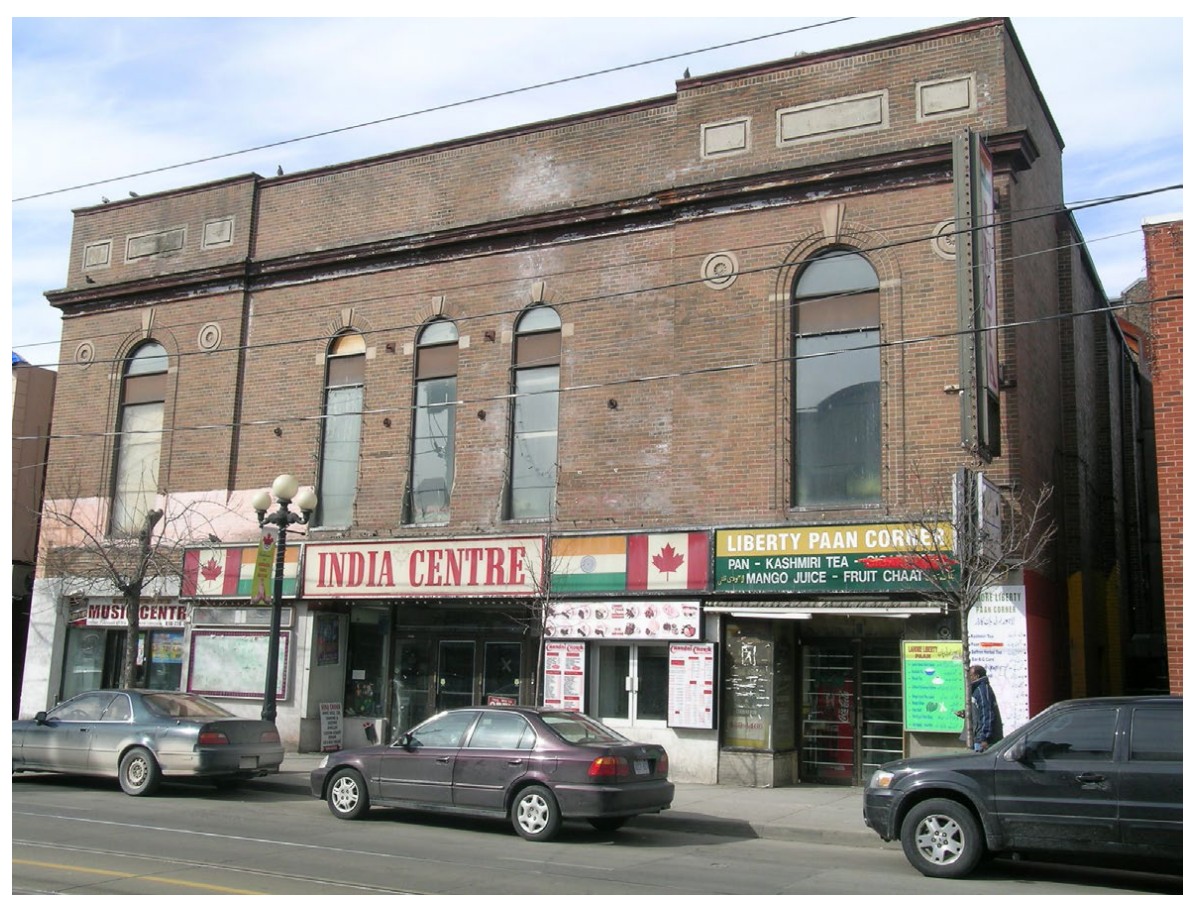

Figure 3. The original Hindi movie theatre was once occupied by commercial and office spaces (identified as 'India Centre' in the picture). Local merchants proposed to convert it into a South Asian cultural centre. However, it was later developed as a condominium apartment building.

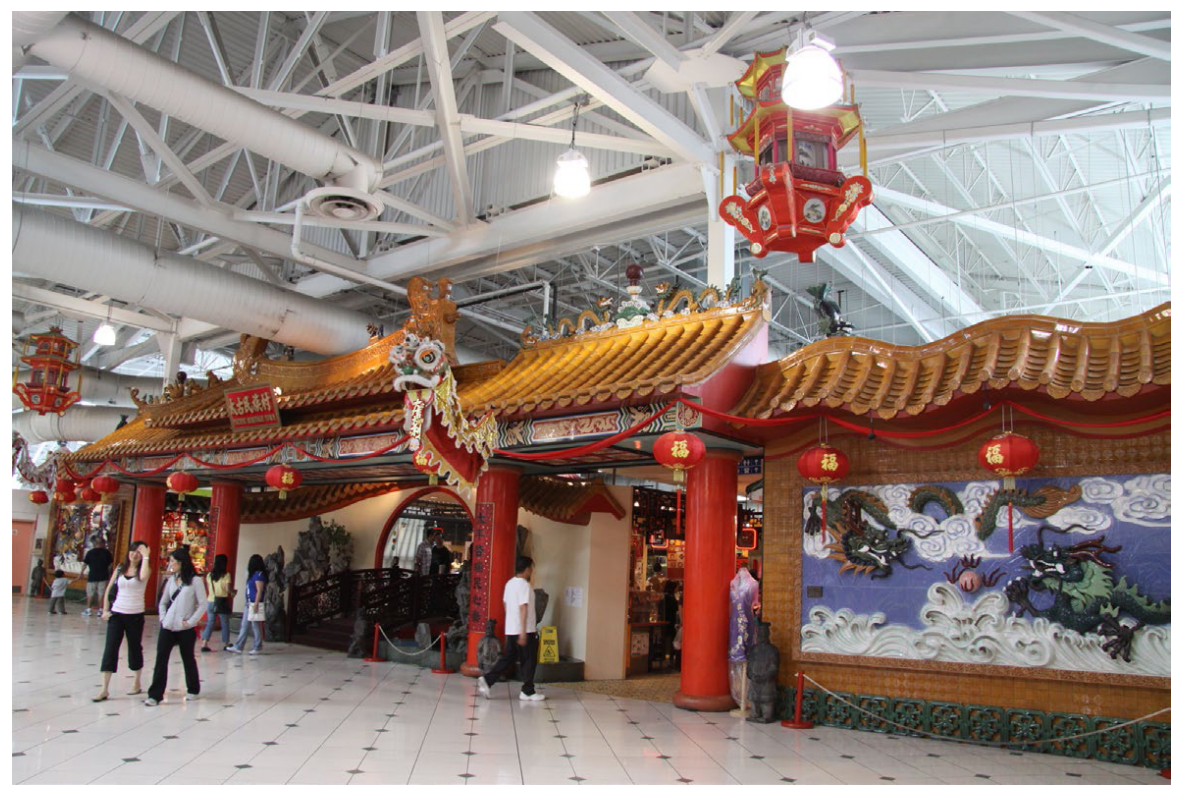

Figure 4. Heritage Town inside the Pacific Mall showcases fragmented pieces of Chinese art and architecture, mixed with imperial and vernacular styles. 
In contrast to these expressions of ethnic identity, Corso Italia tends to exhibit more ethnic assimilation. A previous study focusing on the area's transformation from Little Britain to Little Italy found that merchants were proud to maintain the Italian style of their storefronts and reacted negatively to new immigrant shopkeepers who did not conform to this style (Buzzelli, 2001). However, in the research presented here, interviews with merchants in Corso Italia revealed that most preferred a more toned-down expression of ethnicity, to appeal to a broader customer base. The eight merchants interviewed had various ethnic origins (Italian, Portuguese, and Canadian) and reported owning shops in this area for 10-48 years (30 years on average). When asked about the Italian theme in Corso Italia, and how they would improve their store façade, only two said that the area needed "a stronger Italian image" and should "keep that Italian identity alive." The others favoured a European or neutral theme to target a wider audience (Figure 5). This kind of assimilation is also reflected in debates about the name of the area and its annual festival. To reflect the increasing influence of the Hispanic community from Latin America, merchants decided to change the name of their annual street festival from the Italian festa to the Spanish fiesta, hoping to attract more people from diverse groups. Even the name of the area is currently under debate because 'Corso Italia' no longer reflects the diverse cultures now represented in the area. Identity is expressed less along ethnic lines, and the area is now promoted with a more generally accepted multi-ethnic image.
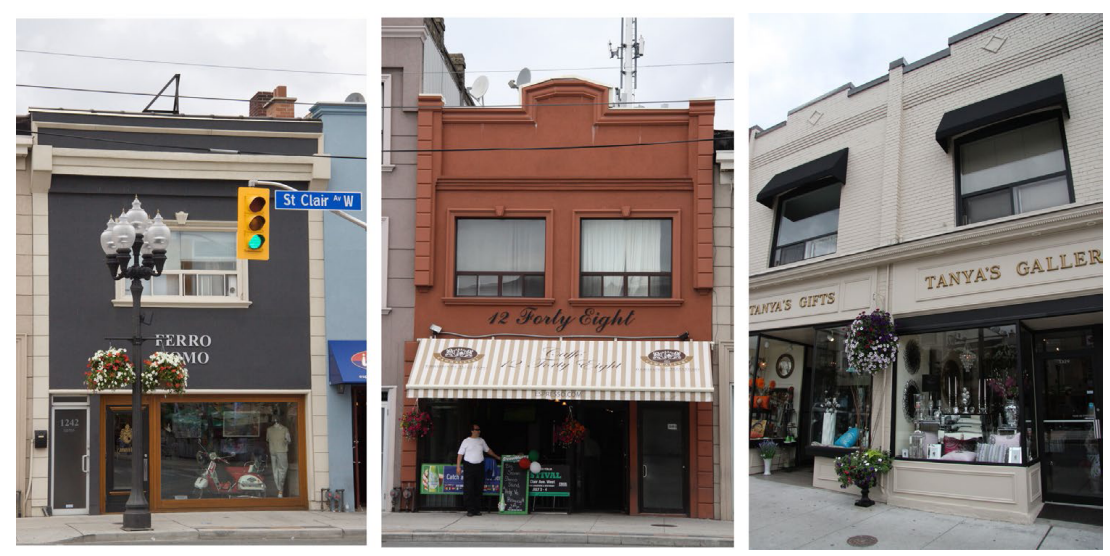

Figure 5. Typical store façade upgrades in Corso Italia feature clean designs and elegant storefronts.

In the context of increased globalization and 'ethnic chic,' the definitions of 'ethnic' and 'mainstream' have become blurred. For example, in the 1960s, outdoor cafes were considered 'ethnic.' Interviews revealed that the first sidewalk cafe in Toronto was established in Corso Italia in the 1960s, when a city councillor (Joseph Piccininni, of Italian heritage) was instrumental in issuing the first outdoor cafe permit. Now, outdoor cafes are everywhere and are considered mainstream. Even mainstream chain stores (e.g., Walmart, Loblaws, No Frills) in the Greater Toronto Area have now begun to target the 'ethnic' market, stocking a large variety of Asian foods and products (e.g., sushi, rice cookers, Cantonese barbequed meat), and even providing Chinese translations. Thus, the ethnic retail sector is not segregated from the general economy: a two-way process is occurring between 'ethnic' and 'mainstream' markets. 
This two-way penetration was confirmed by quantitative business survey data obtained from CSCA. Table 3 shows a trend toward a smaller proportion of business establishments with ethnic content in three of the four study sites (the exception is East Chinatown), indicating a shift away from ethnic markets and toward universal markets. However, this finding does not mean that fewer ethnic entrepreneurs own businesses in these areas: observations and interviews in this study revealed that most small-business entrepreneurs in the study areas are ethnic minorities. The CSCA's definition of 'ethnicity' is based only on the ethnic component of store signage and merchandise, regardless of the ethnic background of the storekeeper/owner. Still, the data correctly suggest that ethnic businesses in these areas are trying to expand their clientele by carrying more general merchandise for wider audiences.

Table 3: Ethnic Content of Businesses in the Four Studied Areas from 2000-2009

Source: CSCA Business Survey Data, 2010

\begin{tabular}{|l|l|l|l|l|l|l|l|l|l|l|l|}
\hline & Ethnicity & $\mathbf{2 0 0 0}$ & $\mathbf{2 0 0 1}$ & $\mathbf{2 0 0 2}$ & $\mathbf{2 0 0 3}$ & $\mathbf{2 0 0 4}$ & $\mathbf{2 0 0 5}$ & $\mathbf{2 0 0 6}$ & $\mathbf{2 0 0 7}$ & $\mathbf{2 0 0 8}$ & $\mathbf{2 0 0 9}$ \\
\hline $\begin{array}{l}\text { East } \\
\text { Chinatown }\end{array}$ & Chinese & $60.7 \%$ & $59.9 \%$ & $55.9 \%$ & $57.8 \%$ & $61.6 \%$ & $61.6 \%$ & $62.8 \%$ & $61.8 \%$ & $62.5 \%$ & $71.1 \%$ \\
\hline & $\begin{array}{l}\text { No Ethnic } \\
\text { Content }\end{array}$ & $35.6 \%$ & $36.0 \%$ & $40.0 \%$ & $37.3 \%$ & $34.1 \%$ & $34.6 \%$ & $33.1 \%$ & $34.2 \%$ & $33.6 \%$ & $22.5 \%$ \\
\hline $\begin{array}{l}\text { Gerrard } \\
\text { India Bazaar }\end{array}$ & $\begin{array}{l}\text { Indian/ } \\
\text { South Asian }\end{array}$ & $60.2 \%$ & $61.5 \%$ & $63.5 \%$ & $63.3 \%$ & $63.4 \%$ & $61.4 \%$ & $60.7 \%$ & $57.3 \%$ & $56.9 \%$ & $55.3 \%$ \\
\hline $\begin{array}{l}\text { No Ethnic } \\
\text { Content }\end{array}$ & $35.2 \%$ & $35.4 \%$ & $34.1 \%$ & $34.4 \%$ & $35.1 \%$ & $37.9 \%$ & $37.0 \%$ & $41.2 \%$ & $41.5 \%$ & $44.0 \%$ \\
\hline $\begin{array}{l}\text { Italian/ } \\
\text { Eurso Italia }\end{array}$ & $44.1 \%$ & $45.0 \%$ & $39.1 \%$ & $37.4 \%$ & $34.8 \%$ & $34.1 \%$ & $32.1 \%$ & $32.1 \%$ & $27.9 \%$ & $27.1 \%$ \\
\hline & $\begin{array}{l}\text { No Ethnic } \\
\text { Content }\end{array}$ & $53.5 \%$ & $52.7 \%$ & $57.9 \%$ & $59.7 \%$ & $63.1 \%$ & $63.0 \%$ & $65.0 \%$ & $65.0 \%$ & $69.0 \%$ & $70.0 \%$ \\
\hline
\end{tabular}

\section{Meanings of Ethnic Expressions: Ethnic Pride vs. Commodification of Ethnicity}

Decoding the meanings of ethnic expressions in retail landscapes is difficult, due to the complexity of ethnic pride and the commodification of ethno-cultural diversity. The following sections compare 'old' and 'new' Chinatowns (East Chinatown and Pacific Mall), and then explore how the City of Toronto's Business Improvement Area (BIA) program affected expressions of identity in India Bazaar and Corso Italia.

In East Chinatown, entrepreneurs continue to rely on typical Chinese components, such as the archway, to maintain their neighbourhood and businesses. Historically, Chinatowns have combined complex social, political, economic, cultural, and racial factors. They have had 
multiple meanings across different periods of time: from isolated ghettos in their early years and slums during peaks of urban renewal (in Canada, 1950s-1960s), to tourist spots, well-recognized ethnic residential and commercial neighbourhoods, and symbols of the recent age of multiculturalism (Lai, 1988). Lai defined Chinatown as "basically an idiosyncratic oriental community amidst an occidental urban environment" (1973, p. 101), which illustrates the common conceptualization of Chinatown as a colony of the East in the West.

In contrast, Anderson argued that the creation of Chinatowns in the Western world is a physical manifestation of a "cultural abstraction that belongs to the beliefs and institutional practices of white European society" (1991, p. 8) - that 'Chinatown' is in part a European creation. Her findings challenged conventional wisdom, although she was aware that she had excluded the perspectives of Chinatown residents.

The archway in East Chinatown reflects certain aspects of both schools of thought (Chinatown as an Eastern colony, and as a European creation): the internal and external factors that determine how local businesses and larger society tend to define Chinatown and the expression of Chinese ethnicity in the landscape. It is a well-recognized or stereotypical image of Chinatown, but 'Chinatown' has also become a marketing brand that is exploited for the tourist industry by Chinese merchants and other interest groups. As in theme parks, Chinatowns may use symbolic forms (archways, lanterns, dragon and lion patterns), and the authentic 'Chineseness' of Chinatowns has been questioned: Ley (2005) described them as a 'mistaken identity' that is attractive to tourists but not to well-educated 'hyper-modern' recent immigrants. Still, interviews revealed that merchants in East Chinatown were proud of the archway and considered it "the symbol of the Chinese community." The building materials (worth CDN\$200,000) were donated by the Chinese government, which offered support to help sustain Chinese cultural heritage and reinforce its national identity among the Chinese diasporas. Overall, Chinatowns represent a hybrid cultural form from China and Canada: a kind of cultural metamorphosis that reflects dynamics of a fluid diasporic 'Chineseness.'

Pacific Mall is a kind of suburban 'Chinatown.' The developers decorated Heritage Town with fragmented mix-and-match pieces of Chinese art and architecture (e.g., golden roof tiles and two nine-dragon walls typically found in imperial Chinese palaces, together with Southern China vernacular gardening elements, such as moon-shaped gate, bridge, pond, and stone sculptures). It resembles a miniature theme park and comes across as kitschy. Some merchants criticized it for not representing the 'authentic' cultural image it is intended to convey, and wanted a more authentic cultural atmosphere. Others resisted the expression of Chinese identity altogether, and refused to decorate their own stores in the style of the mall, arguing that products and services are more important than how the mall is decorated. These comments were echoed by shoppers of Chinese heritage, who were attracted to the Mall by its stores but not by its decorations. However, non-Chinese shoppers commented that they were attracted by the shopping ambience in the Pacific Mall: its 'Asian feel' or 'Hong Kong feel.' Together, these findings support previous research suggesting that 'authenticity' can have multiple, subjective, and contradictory meanings. 
Within this context, a number of questions emerge. Who are the active agents selling ethnicity? Whose identity is under discussion? Who is attracted to this kind of ethnic expression? The non-Chinese developers of the Pacific Mall used Chinese cultural motifs to attract tourists and customers, earning profits by commodifying a synthesized Chinese identity. Meanwhile, most Chinese merchants provided cultural products and services to both Chinese and nonChinese customers regardless of the decorations. In other words, while the developers used static physical or architectural forms to create a commodified ethnicity, the merchants provided diverse customers with cultural goods and services that reinforce an 'authentic' Chinese identity. The expression of Chinese ethnicity in the Pacific Mall is therefore multi-layered, conveying genuine and synthesized meanings.

India Bazaar and Corso Italia also exemplify the complexity and ambiguity involved in ethnic pride and commodified ethnicity. Both provide space for day-to-day social life and business practices, i.e., 'authentic' cultural identity. Ethnic entrepreneurs are the major actors in creating such ethnic identity, and co-ethnic customers participating in ethnic retail activities contribute to the accentuation of the identity. For example, the streets in the India Bazaar resemble those in a typical Indian city: in summer, vendors sell corn and sweets on the sidewalks, play traditional music, and display saris and jewelry in shop windows (Figure 6). In Corso Italia, Italian-owned businesses, organizations, and community services (e.g., a large Italian-language book collection in the local library, Roman Catholic churches, social clubs, billiard halls, and bocce courts) leave their mark on the neighbourhood despite ethnic succession. Some buildings have been adapted to meet the needs of Italian businesses: for example, vestibules have been removed to make way for storefront cafe windows to sell ice cream and coffee. The area has a tradition of sidewalk cafes and outdoor patios, with wide sidewalks to accommodate trees and pedestrian activities, reflecting an Italian/European city culture (Figure 7).
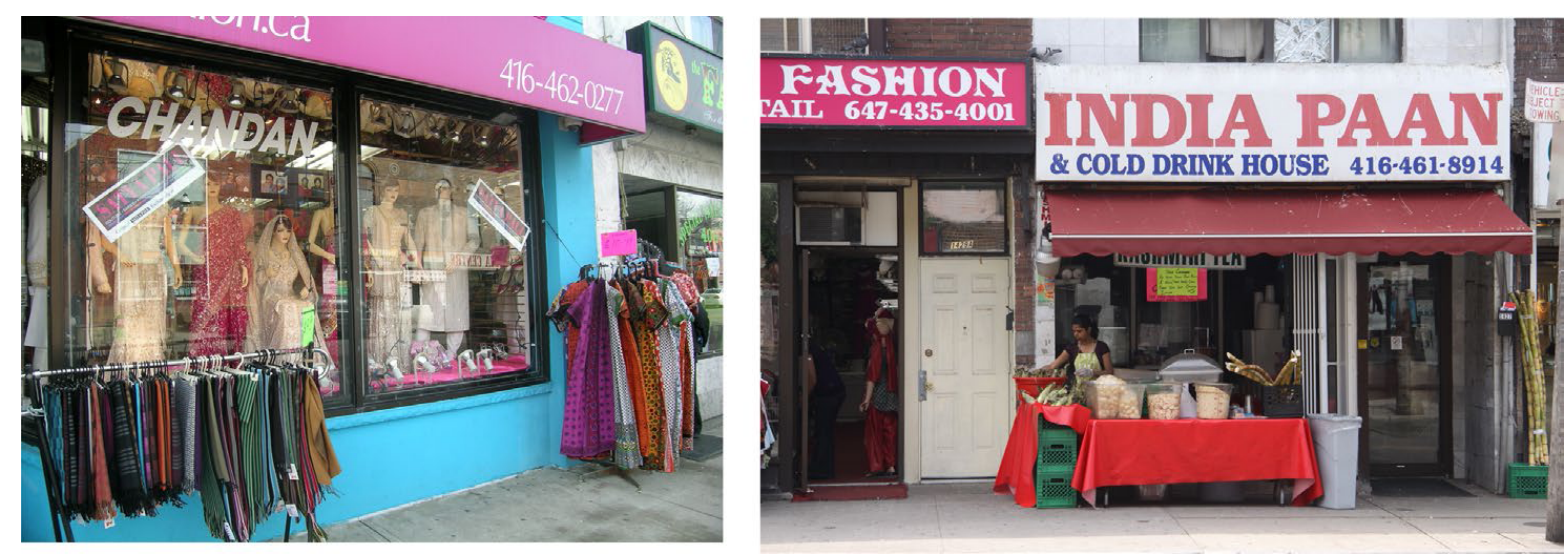

Figure 6. Typical streetscape in Gerrard India Bazaar features colourful window displays and a sidewalk corn stand. 

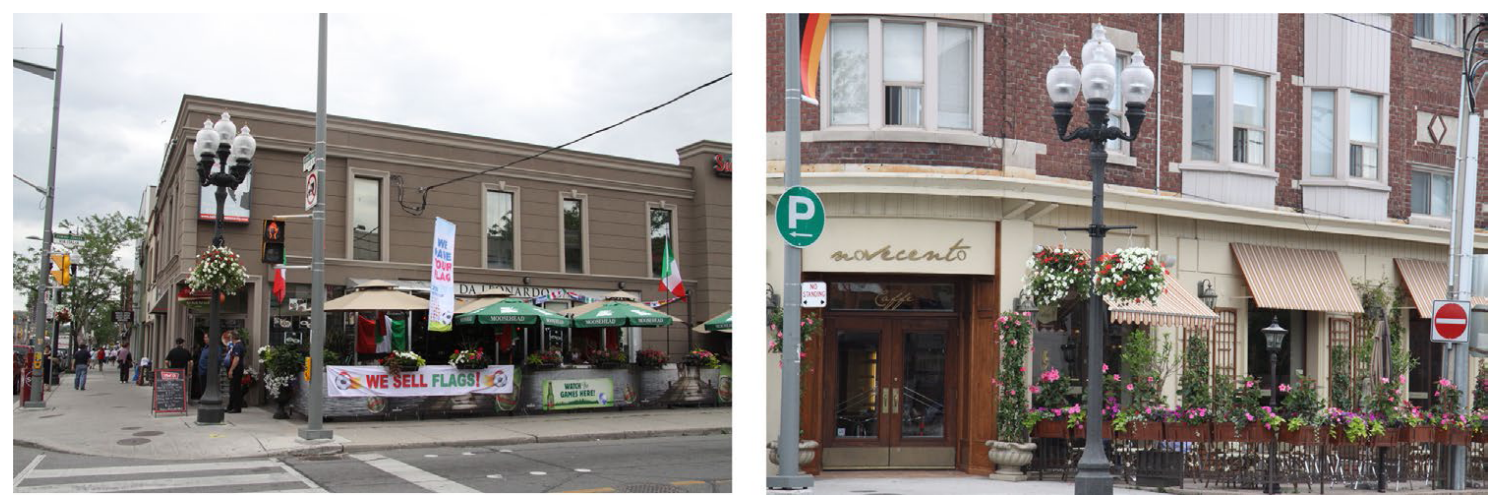

Figure 7. In Corso Italia, sidewalk space is allocated for outdoor cafes and patios.

India Bazaar and Corso Italia also commonly use festivals and cultural events to promote local economic development and construct identity (Rath, 2007). Local merchants use these to promote their businesses and to create a collective image, reconciling the diverse cultural groups in the area. For example, interviews with merchants in the India Bazaar revealed that they came not only from the Indian subcontinent, but also from other parts of the world, with different languages, dialects, and religions. The mixture of religions and faiths among the businesses in the Bazaar is evident, but despite religious conflicts in their countries of origin (e.g., between Hindus, Sikhs, and Muslims), business owners share the desire for economic prosperity and a peaceful life. They organize a series of annual festivals celebrating South Asian cultures, including Festival of South Asia, the Eid Festival (End of Ramadan for Muslims), the Baisakhi Festival (a Punjabi and Sikh celebration of spring in April), the Diwali Festival (Festival of Lights for Hindus), as well as Christmas and New Year celebrations for the Christian community. One merchant said, "We're not only doing businesses, but also celebrating South Asian festivals, culturally speaking." The Corso Italia area has held some of the largest events in Toronto's history: Italian presidential visits in 1967 and 1986; Queen Elizabeth's walking tour in 1984; and celebrations of Italy's World Cup victories in 1982 and 2006, which drew an estimated 200,000 people, many of whom were Italian-Canadians (Buzzelli, 2001, Byers \& Myrvold, 1999). The ethnic pride reflected in day-to-day business practices and community life in both of these areas is undeniably an 'authentic' expression of cultural values and preferences.

Another important aspect in the expression of identity in these two neighbourhoods is the relationship between culture and economics. India Bazaar and Corso Italia were each designated as a Business Improvement Area (BIA) in the early 1980s. ${ }^{3}$ This has allowed them to use standardized beautification and improvement templates to promote a commercial identity that is linked with ethnic identity, whether intended or not. Hackworth and Rekers (2005) explored how the BIA program reproduces cultural identity and how ethnic commercial spaces are used to encourage gentrification in these two areas and two other ethnic BIAs in Toronto. Similarly, Zukin focused on Business Improvement Districts (BID) in the US concluding that BIDs used "uniform design to reinforce their public identity" (1995, p. 66) and created a public culture of "Disney World in the street" (ibid., 34). Since the India Bazaar BIA was established, it has worked to promote the name 'India Bazaar' in the media as a South Asian one-stop shopping 
destination to expand its customer base to include tourists and non-South Asian customers. One long-time business owner who has run his video store in the area since 1979 said that the BIA "wants everybody to experience in India Bazaar ... We don't want just South Asians coming in. We want all different walks of life walking in here. We want them to experience our community." The BIA budget has been used to support community festivals, events, and public art projects such as street murals with cultural symbols to represent a common South Asian theme. These strategies play an important role in shaping the public space and defining the symbolic identity of the retail strip.

Because Corso Italia has gone through several stages of ethnic succession, its BIA hesitated to brand the area as solely Italian. With the influx of immigrants from Latin America to the area, the BIA started to hire Latino event planners to organize the annual fiesta celebrating the cultural traditions of Italians, Portuguese, and Hispanics. One former local councillor commented, “The Italians don't want to give up that Italian identity, but the newcomers [Latin Americans] are saying, even young Italians ... 'you got to go [with] Latin fiesta." As a result, the BIA members collectively decided "to brand [themselves] more as a European destination," according to one BIA business leader. This strategy was implemented via facade upgrades throughout the area carried out since 2003, with the goal of "elegant but not sloppy" storefronts similar to those in Europe, "with fancy canopies and windows." The streetscape was modified to target a mainstream market by promoting a trendy European shopping atmosphere. Thus, the BIA branding strategy affected not only the area's appearance, but also reconstructed its identity to maximize business profits.

\section{Conclusions and Implications for Municipalities}

This study explored the dynamics of ethnicity construction and reconstruction in ethnic retail landscapes and the multiple meanings underlying the visual changes by focusing on four different business areas. Previous research in these four areas provides clues about the changing ethnic landscapes during their historical development (Bauder \& Suorineni, 2010; Buzzelli, 2001; Chen, 2005) and about ethnic gentrification and multicultural planning (Hackworth \& Rekers, 2005). However, they did not fully explore the dynamics of ethnicity construction and reconstruction and the complex meanings of ethnic expression. The present study systemically examined these areas as representations of Canada's multiculturalism: by comparing them, it revealed how ethnicity is manifested, commodified, and reconstructed. The findings provide empirical data to fill the gap in research about ethnic landscapes and the ethnic retail phenomenon.

The four cases revealed a variety of ways through which ethnic businesses express their cultural differences and identities: architectural features, public spaces, public life, commercial activities, and ethnic festivals and branding. These ethnic expressions distinguish these areas from the general urban retail landscape, but vary in terms of their degree of ethnic revival or assimilation, illustrating the complexity of ethnic expressions in retail landscapes. On one hand, ethnic expressions are a way to represent an 'authentic' ethnic culture and to convey ethnic pride; 
on the other hand, they are promoted by businesses as commodity to 'sell' the area. This finding supports previous research suggesting that ethnicity and commerce are intertwined in the making of ethnic retail landscapes, and that the perceptions of 'authenticity' can be multiple, subjective, and contradictory.

However, unlike most previous research, this study found that the major actors promoting the ethnic character in these areas were not local municipalities and regulatory authorities (with the exception of financial support for BIAs): ethnic business communities and developers decided how and to what extent ethnicity should be expressed to maximize an appeal to a wide customer base. This finding supports Lara's conclusions about Latino cultural landscapes in Detroit: "the role of culture in immigrant communities is essential to economic revitalization and placemaking," but "Designers, planners and policy makers often do not give serious consideration to the importance of culture in design. They neglect to factor in the role that culture plays in creating urban resiliency in our communities" (2012, pp. 147-148). Here, resiliency specifically refers to ethnic communities readapting and revitalizing urban space. The case studies exemplify how immigrant businesses succeeded in transforming existing retail spaces and reconstructing the neighbourhood's identity. However, the statutory regulatory frameworks in both Toronto and Markham, particularly the land-use planning policies and urban design guidelines, give no consideration to such ethnic landscapes.

For example, the City of Toronto's Official Plan designates St. Clair Avenue West (Corso Italia) and Gerrard Street East (East Chinatown, Gerrard India Bazaar) as 'Avenues' for higher density and mixed-used developments. St. Clair Avenue West has a designated streetcar right-ofway, which is a precedent for implementing urban intensification in other 'Avenues,' but has caused community disputes because it disrupts the European-style shopping atmosphere. Similarly, designating Gerrard Street East as an 'Avenue' for intensification could negatively affect the neighbourhood's ethno-cultural identity, via future redevelopment pressure. Current planning schemes (e.g., Urban Design Guidelines, Streetscape Manual, and the Avenues and Mid-Rise Buildings Study) only provide city-wide streetscape guidelines and have no specific plans for how the unique ethnic landscapes across the city could be maintained and enhanced. The areas all receive standardized streetscape treatments in terms of paving, trees, medians, lighting, and street furniture (City of Toronto, 2015). In the case of Markham, other than the 'Major Commercial Zone' designation applied to the Pacific Mall, no specific policies have been developed for the highly concentrated Chinese-themed commercial area. Additionally, due to the private ownership of the mall, municipal intervention is limited in terms of built form and associated cultural expression in the streetscape: the developers control what storefronts look like and what cultural meanings they convey.

According to the City of Toronto's Official Plan, "multiculturalism is celebrated and cultural diversity [is] supported" (City of Toronto, 2010, pp. 1-3). The City of Markham's Official Plan also identifies "celebrating diversity" as one of its six policy priorities (City of Markham, 2014, pp. 1-9). However, it does not include specific policies or guidelines as to how diversity can be supported and celebrated, especially with regard to ethnic retail landscapes. As 
Linovski commented about strip malls in Toronto, "current design policies treat all forms in the same manner" - despite the profound diversity in retail landscapes (2012, pp. 97). The current regulatory framework constrains how public policy can enable and enhance expressions of ethnic identity in urban landscapes.

Municipalities should explore creative ways to support immigrant groups in expressing their cultures and lifestyles. City-wide policies, such as official plans, urban design guidelines, and cultural plans should explicitly recognize the ethno-cultural diversity manifested in urban landscapes. Additionally, site-specific policies should be developed in ethic retail areas, which will allow ethnic communities to work with city officials to incorporate cultural expressions on design and planning matters including, but not limited to streetscapes, architectural facades, storefront decorations, sidewalk spaces, signage, street vending, public arts, and community events. Possible policy outcomes could be secondary plans, special area studies, strategic plans, streetscape design guidelines, or comprehensive community improvement plans that will provide city officials with explicit guidance as to how to maintain and enhance such profound ethnic landscapes.

City officials can play a key role in reflecting community needs, optimizing various resources, and improving the physical business environment. Specifically, city planners, urban designers, and economic development officers, as the frontline professionals, are accountable for addressing issues related to neighbourhood changes and expressions of identity, design quality of public spaces, and economic development and revitalization. These professionals cannot initiate ethnic retail activities or manifestations of ethnic identity in urban space; initiatives generally begin with developers or the business community. However, they do need to understand local dynamics and the diversities of each neighbourhood and each ethnic community to help support the multicultural richness of the city and foster socially inclusive and sustainable communities. They also need to be aware that standardized programs or template-based approaches are not appropriate in this context, considering the profound ethnic successions that can occur in urban and suburban neighbourhoods, and the various spatial and physical needs of ethnic communities.

\section{Acknowledgment:}

This paper has been supported by the SRC Grant, Faculty of Community Services, Ryerson University, Canada. The author would like to acknowledge the help of the participants in this study who generously contributed their time and shared their perspectives. They made this research possible. Special thanks go to the anonymous reviewers for their insightful comments. The author is, of course, solely responsible for the content of this paper. 


\section{References:}

Abizadeh, S. \& Ghalam, N. Z. (1994) Immigrants and Canadian-born: a consumption behavior assessment, Social Indicators Research, 32, pp. 49-72.

Anderson, K. J. (1990) Chinatown re-oriented: a critical analysis of recent redevelopment schemes in a Melbourne and Sydney enclave, Australian Geographical Studies, 28, pp.

131-154.

Anderson, K. J. (1991) Vancouver's Chinatown: Racial Discourse in Canada, 1875-1980 (Montreal: McGill-Queens University Press).

Bauder, H. \& Suorineni, A. (2010) Toronto’s Little India: A Brief Neighbourhood History (Toronto: Ryerson Univeristy).

Buzzelli, M. (2001) From Little Britain to Little Italy: an urban ethnic landscape study in Toronto, Journal of Historical Geography, 27(4), pp. 573-587.

Byers, N. \& Myrvold, B. (1999) St. Clair West in Pictures: A History of the Communities of Carlton, Davenport, Earlscourt, and Oakwood (2nd Ed.) (Toronto: Toronto Public Library).

Centre for the Study of Commercial Activity (CSCA) (2010) Annual Business Survey 2000-2009 (Toronto: Ryerson University).

Chan, W.F. (2007) Writing multiculturalism? Planning for culturally different identities in the City of Birmingham, Planning Theory and Practice, 8 (1), pp. 69-85.

Chen, C. (2005) Constructing Pacific Mall, Journal for the Arts, Sciences, and Technology, 3(1), pp. 89-100.

City of Markham (2014) Planning Markham's Future: City of Markham Official Plan. Available at

https:/www.markham.ca/wps/wcm/connect/markhampublic/a7807dcd-9e5f-4bab-b392c5e972428cbe/Official_Plan_Chapter_1.pdf?

MOD=AJPERES\&CACHEID=a7807dcd-9e5f-4bab-b392-c5e972428cbe (accessed March 2, 2015).

City of Toronto (2008a) South Riverdale Neighbourhood Profile. Available at http://www.toronto.ca/demographics/cns_profiles/2006/pdf2/cpa70.pdf (accessed August 30, 2012).

City of Toronto (2008b) Greenwood-Coxwell Neighbourhood Profile. Available at http://www.toronto.ca/demographics/cns_profiles/2006/pdf2/cpa65.pdf (accessed August 30, 2012).

City of Toronto (2008c) Corso Italia-Davenport Neighbourhood Profile. Available at http://www.toronto.ca/demographics/cns_profiles/2006/pdf2/cpa92.pdf (accessed August 30, 2012).

City of Toronto (2010) Official Plan. Available at

http://www1.toronto.ca/static_files/CityPlanning/PDF/chapters1_5_dec2010.pdf (accessed March 2, 2015).

City of Toronto (2015) Streetscape Manual. Available at http://www1.toronto.ca/wps/portal/ contentonly?vgnextoid=0e88036318061410VgnVCM10000071d60f89RCRD (accessed March 10, 2015).

Collins, J. \& Kunz, P. (2009) Ethnicity and public space in the city: ethnic precincts in Sydney. 
Cosmopolitan Civil Societies Journal, 1 (1), pp. 39-70.

Conzen, M. P. (2010) The Making of American Landscape (New York: Routledge).

Cook, I., Crang, P. \& Thorpe, M. (1999) Eating into Britishness: multicultural imaginaries and the identity politics of food, in S. Roseneil \& J. Seymour (Eds.) Practising Identities: Power and Resistance (New York: St. Martin's Press Inc).

Dieterlen, S.( 2014) Hidden in plain sight: design approaches to Midwestern Mexican-American landscapes, Journal of Urbanism: International Research on Placemaking and Urban Sustainability, 7(2), pp. 109-129. DOI: 10.1080/17549175.2013.875055.

Dwyer, C. \& Crang, P. (2002) Fashioning ethnicities: the commercial spaces of multiculture. Ethnicities, 2(3), pp. 410-430.

Gans, H. J. (1979) Symbolic ethnicity: the future of ethnic groups and cultures in America, Ethnic and Racial Studies, 2(1), pp. 1-20.

Groth, P. (1997) Frameworks for cultural landscape study, in: P. Groth \& T. W. Bressi (Eds.) Understanding Ordinary Landscapes, pp. 1-21 (New Haven: Yale University Press).

Hackworth, J. \& Rekers, J. (2005) Ethnic packaging and gentrification: the case of four neighbourhoods in Toronto, Urban Affairs Review, 41(2), pp. 211-236.

Halter, M. (2000) Shopping for Identity: The Marketing of Ethnicity (New York: Schocken Books).

Hayden, D. (1995) The Power of Place: Urban Landscapes as Public History (Cambridge, London: MIT Press).

Hayden, D. (1997) Urban landscape history: the sense of place and the politics of space, in: Groth, P. \& Bressi, T.W. (Eds.), Understanding Ordinary Landscapes, pp. 111-133 (New Haven: Yale University Press).

Irazabal, C. and Gomez-Barris, M. (2007) Bounded tourism: immigrant politics, consumption, and traditions at Plaza Mexico. Journal of Tourism and Cultural Change, 5(3), pp. 186-213. Jackson, P. (2002) Commercial cultures: transcending the cultural and the economic, Progress in Human Geography, 26(1), pp. 3-18.

Jenkins, R. (2008) Rethinking Ethnicity: Arguments and Explorations (2nd Ed.) (London: Sage). Kaltmeier, O. (2011) Selling EthniCity : Urban Cultural Politics in the Americas (Burlington, VT: Ashgate).

Kaplan, D. \& Li, W. (2006) Introduction: The Places of Ethnic Economies. In D Kaplan and W Li (Eds.) Landscapes of the Ethnic Economy, pp. 1-14 (Lanham: Rowman and Littlefield). Koc, M. \& Welsh, J. (2002) Food, Foodways and Immigrant Experience (Toronto: Centre for Studies in Food Security, Ryerson University).

Lai, D. C. (1973) Socio-economic structures and the viability of Chinatown, in: C. Forward (Ed.) Residential and Neighbourhood Studies in Victoria, Western Geographical Series. No.5 (Victoria: University of Victoria).

Lai, D. C. (1988) Chinatowns: Towns within Cities in Canada (Vancouver: UBC Press). Lara, J. J. (2012) Patterns and forms of Latino cultural landscapes: southwest Detroit, a case of incremental re-adaptive use, Journal of Urbanism: International Research on Placemaking and Urban Sustainability, 5(2-3), pp. 139-156, DOI: 10.1080/17549175.2012.693127. Ley, D. (2005) Mistaken Identity? Re-thinking Canadian Chinatowns (London, ON.: Canadian Association of Geographer Annual Conference Presentation). 
Li, W. (2009) Ethnoburb: The New Ethnic Community in Urban America (Honolulu: University of Hawaii Press).

Linovski, O. (2012) Beyond aesthetics: assessing the value of strip mall retail in Toronto, Journal of Urban Design, 17(1), pp. 81-99.

Loukaitou-Sideris, A (2002) Regeneration of urban commercial strips: ethnicity and space in three Los Angeles neighbourhoods, Journal of Architectural and Planning Research, 19(4), pp. 334-50.

Noble, A. G. (Ed.) (1992) To Build in a New Land: Ethnic Landscape in North America (Baltimore and London: The Johns Hopkins University Press).

Olson, S.H. \& Kobayashi, A. (1993) The emerging ethnocultural mosaic, in: Bourne, L. \& Ley, D. (Eds.) The Changing Social Geography of Canadian Cities (Montreal, Quebec: McGillQueen's University Press).

Pang, C. L. (2012) Gateways to the urban economy : Chinatowns in Antwerp and Brussels, in: V. Aytar \& J. Rath (Eds.) Selling Ethnic Neigborhoods: The Rise of Neighbourhoods as Places of Leisure and Consumption (New York: Routledge).

Phan, M. B. \& Luk, C. (2008) 'I don't say I have a business in Chinatown': Chinese sub-ethnic relations in Toronto's Chinatown West, Ethnic and Racial Studies, 31(2) pp. 294-326.

Qadeer, M. (1999) The Bases of Chinese and South Asian Merchants'Entrepreneurship and Ethnic Enclaves, Working Paper (Toronto: CERIS).

Rath, J. (2007) The Transformation of Ethnic Neighbourhoods Into Places of Leisure and Consumption, Working Paper 144 (University of California, San Diego: The Centre for Comparative Immigration Studies).

Robson, K. \& Neuman, W. L. (2012) Basics of Social Research: Qualitative and Quantitative Approaches (Toronto: Pearson Education Canada).

Schnell, S. M. (2003) The ambiguities of authenticity in 'Little Sweden', U.S.A., Journal of Cultural Geography, 20(2), pp. 43-68.

Shaw, S. (2010) Marketing ethnoscapes as spaces of consumption: 'Banglatown-London's curry capital', Journal of Town and City Management, 1(4), pp. 381-395.

Statistics Canada (2006) 2006 Census: Profile of Census Tracts. Available at http://dc1.chass.utoronto.ca.ezproxy.lib.ryerson.ca/cgi-bin/census/2006/ displayCensusCT.cgi?lang $=\& \mathrm{c}=\mathrm{eth} \& \mathrm{p}=\& \mathrm{l}=\& \mathrm{geot}=\mathrm{s} \& \mathrm{ct}=($ accessed August 15,2013$)$. Statistics Canada (2010) Canada's Ethnocultural Mosaic, 2006 Census: Canada's Major Census Metropolitan Areas. Available at https://www12.statcan.gc.ca/census-recensement/2006/as-sa/97-562/p21-eng.cfm (accessed May 20, 2013).

Taylor, I. (2000) European ethnoscapes and urban redevelopment: The return of Little Italy in 21st century Manchester, City 4(1): 27-42.

Teixeira, C. (2006) Residential segregation and ethnic economies in a multicultural city: the little Portugal of Toronto, in: D. Kaplan \& W. Li (Eds.) Landscapes of the Ethnic Economy, pp. 4966 (Lanham: Rowman and Littlefield).

Thompson, R. H. (1989) Toronto's Chinatown: The Changing Social Organization of An Ethnic Community (New York: AMS Press).

Upton, D. (1986) America's Architectural Roots: Ethnic Groups That Built America 
(Washington, D.C.: Preservation Press).

Wang, S. (1996) New Development Patterns of Chinese Commercial Activity in the Toronto $C M A$. (Toronto: Centre for the Study of Commercial Activity, Ryerson University).

Wang, S. \& Zhong, J. (2013) Delineating Ethnoburbs in Metropolitan Toronto, Working Paper No. 100 (Toronto: CERIS).

Wood, J. (1997) Vietnamese American place making in Northern Virginia, Geographical Review, 87(1), pp. 58-72.

Yin, R. K. (2009) Case Study Research: Design and Methods (4th Ed.) (Los Angeles: Sage

Publications).

Zelinsky, W. (1991) Seeing beyond the dominant culture, Places, 7, pp. 33-35.

Zelinsky, W. (2001) The Enigma of Ethnicity: Another American Dilemma. (Iowa City:

University of Iowa Press).

Zukin, S. (1995) The Cultures of Cities (Cambridge, MA: Blackwell).

${ }^{1}$ Before the 1960s, Canada's immigration policy restricted immigration quotas and assessed immigrants on the basis of race and national origin. During the 1960s, a new Immigration Act was introduced to remove racial discrimination and recognize education and skills as major immigrant selection criteria.

2 Italians were among the earliest immigrant groups to settle in Toronto and are still one of the largest ethnic groups in Canada, even though the Italian immigrant population has declined since the 1970s. The Chinese also have a long immigration history in Canada. In contrast to the Italians, the post-1967 immigration waves favored by the new immigration policy boosted the Chinese group as the second-largest visible minority group according to the 2011 Canadian Census. South Asians have much shorter mass immigration history than the other two groups, but have quickly become the largest visible minority group.

${ }^{3} \mathrm{~A}$ BIA is a voluntary association of local business persons and property owners within a specified boundary, who work together in partnership with the city to improve and promote their business area. The City of Toronto collects a special tax levy from BIA businesses and the funds are used for purposes such as streetscape improvement, event planning, marketing, and promotional campaigns. It also provides 50/50 matched capital funding for streetscape improvements, such as façade upgrade. 